REVIJA ZA ELEMENTARNO IZOBRAŽEVANJE

JOURNAL OF ELEMNTARY EDUCATION

Vol. 13, No. 2, pp. 153-168, Junij 2020

\title{
INTERACTIVE EFFECTS OF ACOLOUR WHEEL Motion GaMe on Pupils' Cognitive DEVELOPMENT IN GRAPHIC ARTS
}

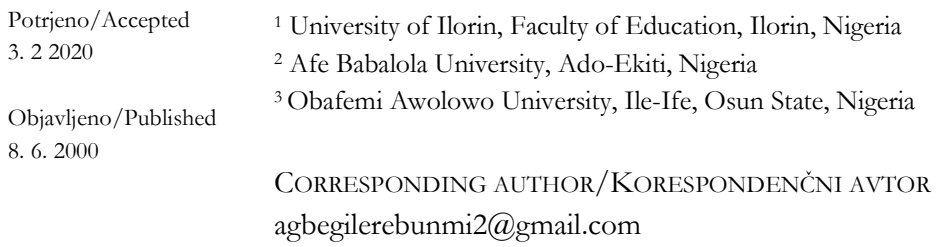

Michael Olubunm Odewumi ${ }^{1}$, Adekunle Olusola Otunla ${ }^{2}$ \& Tayo ABASS BADA ${ }^{3}$

Abstract/Izvleček Games can be instruments for fun and competition globally. However, despite their relevance for instruction, the awareness of key games and their use have not been significantly established. Therefore, the study investigates the interactive effects of colour wheel motion games on pupils' cognitive development in the field of graphic arts. The study included a pre-test and a post-test. The sample comprised 50 pupils: 25 boys and 25 girls. Two research hypotheses were tested. Findings revealed a significant difference between groups (experimental and control) and gender (boys and

Keywords: Colour, Creative Arts, Game, Gender, Graphic arts.

Ključne besede: barva, ustvarjalna umetnost, igra, spol, grafična umetnost

UDK/UDC 37.015.31:76 girls). Nevertheless, the use of the Colour Wheel Motion Game for learning was recommended for all pupils in secondary schools in Nigeria.

Interaktivni učinki gibalne igre $\mathrm{z}$ barvnim kolesom na kognitivni razvoj učencev pri grafiki

Igra je po vsem svetu sredstvo za zabavo in tekmovanje, a zavest o tem in uporaba igre kljub njenemu pomenu za učenje še nista zadosti uveljavljeni. Študija zato proučuje vzajemne učinke gibalne igre $\mathrm{z}$ barvnim kolesom na kognitivni razvoj na področju grafične umetnosti. Vključuje predhodno in naknadno testiranje; v vzorcu je bilo 50 učencev - 25 dečkov in 25 deklic. Preverjali smo dve raziskovalni hipotezi. Ugotovitve so pokazale pomembne razlike med učenci, ki so bili izpostavljeni gibalni igri z barvnim kolesom, in tistimi, ki niso bili. Uporaba gibalne igre z barvnim kolesom za učenje je priporočena ne glede na učence in spol. 


\section{Introduction}

Colour is seen everywhere. Its origin and usage have been traced to cave men. Colour has been used by individuals as a symbolic and informative medium (Kumar \& Joshi, 2006; Odewumi \& Okonkwo, 2017; Schloss, Lessard, Walmsley \& Foley, 2018). Hence, colour is the effect of light on an object. It is used for beautifications and considered a very important phenomenon that promotes information in visual form. Colour is sometimes called pigment (Johnson, 2014).

The study by Kurt and Osueke (2014) explained that colours are divided into primary, secondary and tertiary types. The authors further listed primary colours as red, blue and yellow, which are generally believed to be the origin of the other colours. This is because other colours are manufactured from them. On the issue other colours, Usman, Odewumi, Obotuke, Apolola and Ogunyinka (2014) acknowledged grey, white and black as neutral colours. These are also not the result of any colour mixture; instead, ash or grey having as components equal proportions of both white and black. Nevertheless, grey stands out in the background of other relative colours (Odewumi, Okeke, Abdulhammed, Uzoma, \& Okeke, 2015). Colours can sometimes be differentiated on the basis of intensity, either darker or lighter in relation to the original colour, called the hue. In this regard, hue is the name given to the undiluted colour. The study by Odewumi, Adeniran and Falade (2018) proposed that the tones of both the brightness and the amount of shade produce tonal gradation of colour in terms of light and shade that varies a particular colour to produce varieties of colour for instruction.

Colours feature prominently in instruction; the value and worth are emphasised by researchers of teaching and learning. For example, the study by Olurinola and Omoniyi (2015) established colour as a positive means of retaining and sustaining undergraduate students' attention in an educational programme. In the same vein, Smilek, Dixon, Cudahy and Merikle (2002) found that colour perception by students from a wider computer screen revealed that students performed better in relation to matching the colour on the computer screen. Similarly, Onasanya (2002) established that the achievement of students exposed to coloured photographic prints was of great value when compared with their peers who had been exposed to black and white prints. However, this shows a distinct marginal gain over black and white photography. Moreover, colour sustains and stimulates the attention of learners; it 
also grants the stimulus that is important for cognitive retention and boosts learning. Moreover, colour influences the readability of web-based e-learning materials on a defined range of the spectrum (Anderson, Muller \& Hillyard, 2009; Richardson, Drexler \& Delparte, 2014).

The colour spectrum attracts more attention than the colour wheel for instruction. A colour wheel exhibits colours in groups, and the components of both primary and secondary colours in a unique sphere. A study conducted by Bell (2013) established that the creation of a colour wheel is anchored to the wavelength of the seven colours on the spectrum. Similarly, Westfall (1962) explained the colour wheel as a string of unadulterated hues arranged credibly in a perfect circle. In the same vein, a colour wheel is a sphere comprising colours arranged in alternating primary and secondary colours (Pitchford \& Mullen, 2005). Essentially, a colour wheel commonly guides the production and use of colours for instructional materials and games.

Globally, it has been realized that games form an integral part of both formal and informal education (Skwarchuk, Sowinski\&LeFevre 2014; Dehkordi, 2017). Educational games can be applied and used in institutions of learning and homes. Ke (2008) established that when games no longer distract the attention of learners but inculcate learning and aid pupils' intellectual development, they can be said to be instructional games. A good environment constitutes a great opportunity for learning, and instructional games offer opportunities for continuity, even though negative consequences are a welcome part of the game and serve as a component part of the learners experience (Gee, 2009; Klopfer, Osterweil \& Salen, 2009; Groff, Howells, \& Cranmer, 2010).The study of Deubel (2013) classified games into two types-technological and non-technological games-based on the instructions. Additionally, Ash (2010) explained that games having the advantage of constant assessment, which arises as the player evaluates and receives immediate feedback.

However, Aleson-Carbonell and Guillén-Nieto (2012) stressed as paramount the significance of games being used in the context of instruction and as a supplement to classroom directives. The arrangement and structure of these games promote educational motivation for pupils to learn easily (Johannesson \& Lundqvist, 2012). A study by Charsky (2010) maintained that there were complexities in identifying and classifying games in the context of their use for instruction. Games are pedagogical tools that develop pupils' intellectual abilities, while also promoting self- 
confidence, which yields positive performances of pupils in instruction (Boyle, 2011; Backlund \& Hendrix (2013).

Previous studies have established the usefulness of games. In fact, Egenfeldt-Nielsen (2016) found that games improve memorization; this, in turn, stimulates cognitive learning by pupils and promotes pupil health. Games broaden the pupils' experiences and improve learning (Wastiau, Kearney and Van den Berghe, 2009). Games encourage constant practicing to avoid failure (Groff, Howells \& Cranmer, 2010). They can encourage pupil self-actualisation (Fleer, 2010). Games also provide opportunities for formative instruction (Heritage, 2010). Learners are more active in a game when there is space for narration of stories within the game, and this helps with many learning issues (Barab, Arici \& Jackson, 2005).

Poor performance and lack of interest in graphic arts among primary school pupils constitute a problem in Nigerian elementary schools. Consequently, efforts have continuously been made to improve teaching and learning because these are the foundation on which the life education of the individual is built. For example, the study by Herga, Čagran and Dinevski (2016) mentioned that lack of motivation among instructors is a crucial factor in the poor performance of pupils in school. Similarly, Copriady (2014) established that teacher competence is paramount in the education of learners; therefore, unqualified teachers are a problem in the elementary education of pupils. Moreover, Olorundare (2014) identified poor instructional materials and methods. The study by Schutt and Linegar (2013), along with Omorogbe and Celestine (2013), agreed that the abstract nature of some subjects on the school curriculum contributed to the problem. Celestine (2013) also identified inadequate and inexperienced teachers as a predicament in teaching and learning. Archibong (2012) pointed out poor timetabling for lessons, while Gambari (2010) mentioned the lack of relevant textbooks. Despite these problems, Li and Qiu (2018) stressed that parental background has a major influence on the educational process of their children. Therefore, integrating games into the school curriculum will go some way towards solving educational problems.

The use of traditional instructional tools such as games in instruction is becoming a burning issue among instructors and educational institutions. Although gaming as instruction could be seen as an intrusion on learning, the role of the educator should be to increase learners' motivation and engagement, to promote skill acquisition, and 
to develop learner interaction and collaboration, especially with their peers, allowing them to actualise gaming values in real-world situations (Wendel, Hertin, Göbel, \& Steinmetz, 2010; Simsek, 2016).

Furthermore, studies even argue that the performance of males and females using games differs. For example, a study by Achor and Imoko (2010) established that games reveal a significant effect by gender on pupils' achievement. Also, Adeleke (2008) discovered that boys' and girls' performances are not equal, and there is significant difference in their performances. In the same vein, Bassey, Joshua and Asim (2008) found a significant difference in gender achievement in favour of male students. Nevertheless, Kinzie and Joseph (2008) established that girls more frequently engaged in video games for learning and discovery than their male peers did.

In another development, Maguth, List and Wunderle (2015) examined the influence of video games on the teaching of world history. The study established that video games provide learners with a digitally relevant world that facilitates the learning of both abstract concepts and theories. Similarly, Bunch, Robinson, Edwards and Antonenko (2014) compared the effect of instruction by lecture and discussion to digital, game-based instruction on learner achievement in both agriculture and mathematics; the study shows that using digital games in the agricultural context of animal science does promote learners' achievement. Furthermore, a study by Ibitoye and Olaifa (2018) evaluated indigenous Yoruba Language Learning through a Game-based Model; the study assesses the cognitive knowledge of game users in term of language, coaches the users through a range of amusing game stages, and predicts the situation of the language learners by using a two-level predictive analytics technique.

This study confirmed the relevance of games in the context of teaching and learning, which has been the focus of many scholars in education. Although educational games serve as a support tool in teaching and learning, studies on games for instruction have been relatively scarce globally. The existing literature reports that games provide learning opportunities in diverse disciplines through collaboration. The study of McLaren, Adams, Mayer and Forlizzi (2017) researched game instruction in Mathematics, concluding that students learn more about decimal points through games. Also, Kao (2014) conducted research on the effect of learning 
English with a digital, game-based tool; the study meta-analysis established that digital games were more effective in transmission of theoretical knowledge collaboratively than individually in practical applications.

In another development, scholars have revealed the significance of graphics in the context of creative arts. For example, Mustamir (2019) studies how to improve learning in the Cultural Arts and Filter Art Graphic Materials among the Class IX E pupils of SMP Negeri 3 Surabaya; the study concluded that the method of screen printing can be improved and learning achieved in filter printing on graphic art resources. Moreover, Odewumi and Idowu (2014)examined Origami (paper folding) in teaching selected graphic arts content to the Junior Secondary School in Ogbomoso, Nigeria. The study revealed the success of paper folding in the graphic world of instruction, and the learning outcomes were positive.

This study therefore determined to fill the gap created by previous studies on the use of games to elicit positive response from pupils based on the classroom teaching of graphics. No known studies of games have included the colour wheel motion game that is the focus of this study. Therefore, the study examined the effect of the colour wheel motion game on pupils' achievement and assessed the interactive effect of this game on pupils' cognitive development in the field of graphic arts, an offshoot of Creative Arts in elementary education in the Nigerian school system.

\section{Research hypotheses}

These two hypotheses were tested in the study:

$\mathrm{HO}_{1}$ : There is no significant difference in achievement of pupils exposed to the colour wheel motion game and of those taught with conventional methods.

$\mathrm{HO}_{2}$ : There is no significant difference in the achievement of male and female pupils exposed to the colour wheel motion game. 


\section{Methodology}

The research design adopted for the study is Quasi-experimental, using pre- and post-testing. The relevant population comprised all primary school pupils in the Ogbomoso North Local Government area of Oyo State, Nigeria, and the sample for the study involved 50 pupils, 25 boys and 25 girls, ranging between 10 and 12 years of age, in Primary five (Basic 5). Pupils were selected from two primary schools (a private and a public school). These were grouped into experimental and control groups.

The criteria for school selection were that both be elementary basic schools, established for the past 15 years. Additionally, trained teachers had to have been teaching the pupils in the school for the past five years. Also necessary was evidence of the pupils' readiness for reading and understanding English. There had to be provision of a classroom with enough space for the exhibition of the game instruments and for pupils to sit conveniently to write the objective paper based on the test items. The study lasted six weeks, with the first week used to familiarise pupils with the game content and playing of the game. The final week was used for evaluation of the Game Curriculum Content (GCC)in the colour card envelope, before the pupils were administered the test instrument i.e. the 'Colour Wheel Rotational Game Test' (CWRGT) as summative.

\section{Research Instrument}

The intervention instrument, the Colour Wheel Rotational Board (CWRB), was developed by researchers in line with model specifications from Morrison, Ross, Kemp, and Kalman (2007).The model comprised nine interrelated phases, from identification of the instructional design problem, to the evaluation unit for the instrument. The intervention game included lesson content adapted for four weeks of intensive instruction. Similarly, a major test instrument, the Colour Wheel Rotational Game Test' (CWRGT), was developed through extraction and selection of questions from the validated Common Entrance Examination for Junior Secondary School in Oyo State, based on relevant topics. In the same vein, the methodologies, coupled with the appropriate instructional media, were used by teachers withthe conventional group. 
The field trial for the Colour Wheel Motion Board (CWMB) was done through administration of the instrument on another set of 15 pupils ( 8 males and 7 females) from another public primary school that is part of the main study populationby two experienced instructors who team-taught the trial. A reliability coefficient of 0.67 was obtained with Kuder-Richardson (KR-20).The comments and suggestions from the experienced instructors were used in producing the final copy of the Colour Wheel Rotational Game and the test items.

\section{Experimental Procedure}

The experimental process was set out in the game guide and manual, which was distributed to both pupils and teachers for proper monitoring of the study. The experimental group, which consisted of 25 pupils, were taught how to rotate the colour wheel. Three different colour wheels were presented to a group of four to five pupils; "ColourWheel A" consisted of a perfect circle, including both primary and secondary colours, in six units and stationed on a large table (Fig. 1). "Colour wheel B" consisted of 15 colour variations, from tertiary colours formed from the secondary colours, and "Colour wheel C" comprised a 12-unit segment of colour terminology. Each pupil holds the edge of the colour wheel motion game board, which rotates anti-clockwise(Fig. 2). When the rotation stops at a point where the arrow is stationed, the pupil picks the white envelope at the back of the unit of colour indicated by the arrow (Fig. 3). The envelope contains a 3- by 4-inchwhite card, which explains the topics and gives detailed content and a summary about each unit of colour reflecting the inverse colour (Fig. 4). These cards were written in bold and placed at the back of each unit segment of colour for the pupils to read in 4 to 5 minutes, afterwards returning the envelope to its place. This was done repeatedly by each pupil; a total of 6 colour wheel motion game boards were presented to pupils in the experimental classroom, to avoid congestion; thus, 4 to 5 pupils could handle each colour wheel motion game board in a group. It should be noted that the experimental group were mandated to participate fully and were well supervised during the gaming process or game playing, with the use of the 3 different colour wheel games provided. 
Each envelope contained adetailed explanation of the teaching content for each colour on the wheel. The conventional group were team-taught the topics (Colours wheel; Primary colours: Secondary colours, Tertiary Colours and Colour terminology) by teachers with assistance from the researchers in the classroom.

The Test Instrument named Colour Wheel Rotational Game Test (CWRGT), was extracted from the validated Oyo State Common Entrance Examination into Junior Secondary Schools past question. The test instrument consisted of three sections, A, $B$ and C. The first Section "A" was for the pupils' name, school and gender; "B" was for the test duration; and " $\mathrm{C}$ for 25 multiple-choice, objective questions. The Colour Wheel Rotational Game Test item on the instrument has five options, "A - E” from which the correct answer can be selected. The CWRGT tests were administered by pencil and paper to the pupils after engaging the students with the (Colour Wheel Rotational Game).This was done in a classroom where pupils were assigned numbers attached to each seat. Scoring of the Colour Wheel Rotational Game Test(CWRGT) items is based on2 marks for the correct answer and 0 for a wrong answer, for a total of 50 obtainable marks. The sixth week witnessed the evaluation of the game and the game content in the envelopes, followed by administration and marking of the test, and handing over pupil scores to the researchers for data analysis.

\section{Hypothesis testing}

$\mathrm{HO}_{1}$ : There is no significant difference in achievement of pupils exposed to the colour wheel motion game and of those taught with conventional methods.

In testing the significant difference in the achievement of pupils taught with the Colour Wheel Motion Game and of those exposed to conventional methods, the hypothesis was tested using ANCOVA with the pre-test serving as covariates. 
Table 1: ANOVOCA Table of Pupils Taught with the Colour Wheel Motion Game and Those Exposed to the Conventional Method.

\begin{tabular}{llllll}
\hline Source & Type III Sum of Squares & Df & Mean Square & F & Sig. \\
\hline Corrected Model & $1351.723^{\mathrm{a}}$ & 6 & 225.287 & 6.173 & .001 \\
Intercept & 5998.089 & 1 & 5998.089 & 164.352 & .000 \\
Pre-Test & 322.606 & 1 & 322.606 & 8.840 & .008 \\
Treatment & 1240.811 & 5 & 248.162 & 6.800 & .001 \\
Error & 656.917 & 18 & 36.495 & & \\
Total & 134796.000 & 25 & & & \\
Corrected Total & 2008.640 & 24 & & & \\
\hline
\end{tabular}

Significant at 0.05 alpha levels.

The results in Table 1 above show the comparison of post-test mean scores for the experimental and control groups. The calculated $\mathrm{F}$ value of 6.800 is significant because the significant value of .000 is lower than the 0.05 alpha levels. This implies that the experimental group exposed to the Colour Wheel Motion Game performed better than the control group taught with the conventional method. The hypothesis is therefore rejected.

$\mathrm{HO}_{2}$ : There is no significant difference in the achievement of male and female pupils exposed to the colour wheel motion game.

In testing the significant difference in the achievement of boys and girls taught with the Colour Wheel Motion Game, the hypothesis was tested using t-test statics to compare the mean for both boys and girls, as shown in Table 2.

Table 2: t-test Statistics for Boys and Girls Taught with the Colour Wheel Motion Game

\begin{tabular}{lcccccc}
\hline Variables & No & Mean & SD & df & t-value & p-value \\
\hline Boys & 25 & 69.00 & 12.24 & & & \\
Girls & 25 & 31.00 & 5.55 & & & \\
\hline
\end{tabular}

The t-test result displayed in Table 2 above shows that the P- value is not greater than 0.05 ; this indicates that there is a significant difference in the mean performance between boys and girls in the two schools. Thus, the null hypothesis was not retained. 


\section{Discussion of the findings}

The study on the interactive effects of the colour wheel motion game on pupils' cognitive development in the field of graphic artsin Nigeria has proved to be positive and useful for instruction. The results from the testing of hypothesis one show a clear and significant difference between the mean figures for pupils exposed to the Colour Wheel Motion Game and the figures for those taught the conventional way. This is an indication that the pupils exposed to the Colour Wheel Motion Game have higher academic achievement than those taught the conventional way. Analysis of hypothesis two shows that there is a significant difference in the mean for boys and girls exposed to the Colour Wheel Motion Game; the mean for the boys' achievement was notably higher than that of the girls. The boys' achievement level on the colour wheel game can be rated higher than that of the girls.

The findings agreed with the study of Pintrich (2003),who confirmed that games promote the intellectual abilities of learners and build learner self-confidence. Our findings were also in agreement with those of Boyle (2011), who established that games were effective in developing learners' cognitive domain. Similarly, the findings are in line with the study by Mayer (2014), which uncovered a relatively slight difference in comparison with conventional methods in teaching mathematics. Moreover, the findings concur with the study by Clark, Tanner-Smith and Killingsworth (2015), who reported that educational games were positive and effective in classroom instruction. The findings also support those of McLaren, Adams, Mayer and Forlizzi (2017), who reported that games are significantly beneficial and more enjoyable forms of instruction.

These findings contradict the study by Zirawaga, Olusanya and Maduku (2017),whose findings revealed that learners who rely on games are occasionally secluded from social life interaction. The findings are also opposite to those from the study by Johnson and Mayer (2010), whose findings demonstrated pupils learning advantages for pupils of self-explanation in educational games. 


\section{Conclusion}

Overall, the study of the interactive effects of this colour wheel motion game on pupils' cognitive development in the field of graphic arts proved to be positive in the given instruction. The colour wheel motion game has proven to be an educational game that promotes meaningful learning among learners. Moreover, the colour wheel motion game can also be grouped with the technology of instruction, instructional packages, and instructional devices in teaching and learning processes that uphold the significance of learning. The study also established that colour concepts and terminology can be learned easily through the use of the colour wheel motion game. This is a clear indication that each player can express their cognitive knowledge about the colours acquired from the colour wheel game by performing excellently on the given test. The colour wheel motion game promotes social skills, interaction and collaboration among pupils. Additionally, the colour wheel motion game builds pupils' interest in active learning. Overall pupils' exposure to frequent operation of the rotational wheel builds muscular fitness and develops the pupils' psychomotor domain.

In relation to the findings from the study, it was ultimately recommended that teachers should be using the Colour Wheel Rotational Game for teaching primary colours, secondary colours, and tertiary colours among primary school pupils in the field of graphic arts. The stakeholders should embrace using the colour wheel motion game in the teaching and learning of colours and other related topics in the curricula context. Overall, sharing, findings on the use and outcome of the colour wheel motion game at the relevant association meetings, seminars and conferences will promote awareness and make learning more meaningful.

\section{References}

Adeleke, M. A. (2008). Strategic improvement of mathematical problem-solving performance of secondary school students using procedural and conceptual learning strategies. The African Symposium: An Online Journal of African Educational Research Network, 8(1), 143-149.

Aleson-Carbonell, M. \& Guillén-Nieto, V. (2012). Serious games and learning effectiveness: The case of it's a deal. Computers \& Education, 58(1), 435-448.

Achor, E. E., Imoko, B. I. (2010). Sex differentials in students' achievement and interest in geometry using games and simulations technique. Necatibey Faculty of Education Electronic Journal of Science and Mathematics Education, 4(1), 1-10 
Anderson, S. K., Muller, M. M. \& Hillyard. S. A. (2009).Colour-selective attention need not be mediated by spatial attention. Journal of Vision, 9(6), 1-7.

Archibong, M. (2012, August 26). We used to lure students to study fine art. The Sun News. Retrieved from http://sunnewsonline.com

Ash, K. (2010). Digital gaming goes academic. Education Week, 30, 2(5), 24-28.

Backlund, P. \& Hendrix, M. (2013). Educational games - are they worth the effort? A literature survey of the effectiveness of serious games. 2013 5th International Conference on Games and Virtual Worlds for Serious Applications (VS-GAMES). http://dx.doi.org/10.1109/vs-games.2013.

Bassey, S. W., Joshua M. T. \& Asim, A. E. (2008). Gender differences and mathematics achievement of rural senior secondary students in Cross River State, Nigeria. Proceedings of International Conference to Review Research in Science, Technology and Mathematics.

Barab, S. A. Arici, A. \& Jackson. C. (2005). Eat your vegetables and do your homework: A designbased investigation of enjoyment and meaning in learning. Educational Technology, 45(1),1520.

Bell, A. (2013). The Effect of Colour on the Audience Response in Theatre Scenic Design. Murdoch University.

Boyle. S. (2011). Teaching Toolkit: An Introduction to Games based learning. UCD Dublin, Ireland: UCD Teaching and Learning/ Resources. 2011. Retrieved from https://www.ucd.ie/t4cms/UCDTLT0044.pdf.pdf

Bunch, J. C., Robinson, J. S., Edwards, M. C. \& Antonenko, P. D. (2014).How a serious digital game affected students' animal science and mathematical competence in agricultural education. Journal of Agricultural Education, 55(3),57-71.

Clark, D. B., Tanner-Smith, E. E., \& Killingsworth, S. S. (2015). Digital games, design, and learning: A systematic review and meta-analysis. 2015. Review of Educational Research. doi:10.3102/0034654315582065

Celestine, A. (2013). Recommendations for Teaching of Higher School Chemistry. American Chemical Society Publishers.

Charsky, D. (2010). From edutainment to serious games: A change in the use of game characteristics. Games and Culture, 5(2), 177-198.

Chohan, S. (2011). Any letter for me? Relationships between an elementary school letter writing program and student attitudes, literacy achievement, and friendship culture. Early Childhood Education, 39(1), 39-50.

Copriady, J. (2014). Teachers competency in the teaching and learning of Chemistry practical. Mediterranean Journal of Social Sciences, 5(8), 312-318.

Dehkordi, M. R. (2017). The educational impact of traditional games: the role of Zurkhaneh sport in educating children. International Journal of Science Culture and Sport, 5(3), 134-139.

Deubel, P. (2013). Game on! [Electronic version]. T. H.E. Journal,1, (2006). Retrieved April 12, 2013. http://www.thejournal.com/articles/17788

Egenfeldt-Nielson, S. (2016). Third generation educational use of computer games. Journal of Educational Multimedia and Hypermedia, 16(3), 263-281.

Fleer, M. (2010). Early Learning and Development. Cultural-historical concepts in play. Melbourne, Australia: Cambridge University Press, (2010), pp. 16-20.

Gambari, A. I. (2010). Effect of instructional models on the performance of junior secondary school students in geometry in Minna, Nigeria. Delsu Journal of Educational Research and Development, 9(1), 54-65.

Gee, J.(2009). Deep learning properties of good digital games: How far can they go? In Serious Games: Mechanisms and Effects (67-82). Routledge Taylor \& Francis Group. https://doi.or$\mathrm{g} / 10.4324 / 9780203891650$

Groff, J., Howells, C., \& Cranmer, S. (2010). The impact of console games in the classroom: Evidence from schools in Scotland. Futurelab,United Kingdom. 2010, 21-30.

Herga, N. R., Čagran, B. \& Dinevski, D. (2016). Virtual laboratory in the role of dynamic visualisation for better understanding of chemistry in primary school,Eurasia Journal of Mathematics, Science \& Technology Education, 12(3), 593-608. 
Heritage, M. (2010). Formative Assessment and next-generation assessment systems: Are we losing an opportunity? Council of Chief State School Officers, Washington, DC 2010, 30-36.

Ibitoye, A. O. J. \&Olaifa, O. T. I. (2018). Predictive Analytic Game-based Model for Yoruba Language Learning Evaluation. International Journal of Modern Education and Computer Science, 2018(2), 43 47. (http://www.mecs-press.org/) DOI: 10.5815/ijmecs.2018.02.05)

Johannesson, M., \& Lundqvist, H. (2012). Understanding Purpose and Circumstantial Context in the Use of Educational Games: designing a search function and updating a Metadata model (Masters). University of Skövde. 2012.

Johnson, C. I. \& Mayer, R. E. (2010). Adding the self-explanation principle to multimedia learning in a computer-based game-like environment. Computers in Human Behaviour, 2010(26), 12461252.

Johnson. P. (2014). Science, performance and transformation: performance for a 'scientific' age? International Journal of Performance Arts and Digital Media, 10(2), 130-142.

Kao, C., (2014). The Effects of Digital Game-based Learning Task in English as a Foreign Language Contexts: A Meta-analysis. Education Journal, 42(2), 113-141.

Ke, F. (2008). A qualitative meta-analysis of computer games as learning tools. In R. E. Ferdig (Ed.), Handbook ofResearch on Effective Electronic Gaming in Education (pp. 1-32). New York: IGI Global.

Kinzie, M. B., \& Joseph, D. R. D. (2008). Gender differences in game activity preferences of middle school children: Implications for educational game design. Educational Technology Research and Development, 56(5-6), 643-663

Klopfer, E., Osterweil, S., \& Salen, K. (2009).Moving Learning Games Forward. Cambridge, MA: The Education Arcade. 2009.

Kurt, S. \& Osueke, K. K. (2014). The effects of colour on the moods of college students. SAGE Open, January-March 2014: 1-12 DOI: 10.1177/2158244014525423

Kumar R. V. \& Joshi, R. (2006).Colour, colour everywhere: In Marketing too. SCMSJournal of Indian Management, 2006. 40-46.

Li, Z., \& Qiu, Z. (2018). How does family background affect children's educational achievement? Evidence from Contemporary China. The Journal of Chinese Sociology, 5(13). https://doi.org/10.1186/s40711-018-0083

Maguth, B. M., List, J. S., \& Wunderle, M. (2015) Teaching Social Studies with Video Games, Social Studies, 106(1), 32-36, DOI: 10.1080/00377996.2014.961996

Mayer, R.E. (2014). Computer Games for Learning: An evidence-based approach. Cambridge, MA: MIT Press.

McLaren, B. M., Adams, D. M., Mayer, R. E. \&Forlizzi, J. (2017). A computer-based game that promotes mathematics learning more than a conventional approach. International Journal of Game-Based Learning (IJGBL), 7(1), 36-56.

Morrison, G. R., Ross, S. T., Kemp, J. E., \& Kalman, H.,(2007). Designing Effective Instruction. John Wiley $\&$ Son Inc.

Mustamir, A. (2019). Application of Demonstration Methods to Improve Learning Achievement in Cultural Arts Subject and Skills of Filter Art Graphic Materials in Class IX-E Students of SMP Negeri 3 Surabaya. Indonesian Journal of Contemporary Education, 1(1), 15-17.

Odewumi, M.O., Adeniran, A. O., \& Falade, A.A. (2018). Pre service fine-arts teachers' disposition to use technology of painting-media for fine-arts instructions in South-West, Nigeria. Discovery, 54(268), 130-138.

Odewumi, B., Okeke, F., Abdulhammed, A., Uzoma, C. \& Okeke, D. (2015). Cultural and Creative Arts for Basic Schools. Primary. Osogbo: Paulmac.

Odewumi, M. O. \& Idowu L. (2014). Origami: Its impact on the Creative Arts Instruction of Junior Secondary School Ogbomoso. Nigeria. International Journal of African Culture and Ideas, (IJACI), 14(1\&2), 258-272.

Odewumi, M. O. \& Okonkwo, I. E. (2017). Effect of painting series package on the performances of junior secondary cultural and creative arts in Ogbomoso, Nigeria. African Journal Online (AJOL), 17(3), 324-333. 
Olorundare, A. S. (2014). Constructivism and Learning in Science. 38th Inaugural Lecture Series, University of Ilorin, Nigeria.

Olurinola, O., \& Omoniyi, T. (2015). Colour in learning: its effect on the retention rate of graduate students. Journal of Education and Practice, 6(14),1-5.

Omorogbe, E. \& Celestine, J. E. (2013). The challenge of effective science teaching in Nigerian secondary schools. Academic Journal of Interdisciplinary Studies, 2(1), 34-45.

Pintrich, P. R. (2003). A motivational science perspective on the role of student motivation in learning and teaching contexts. Journal of Educational Psychology, 95, 667-686.

Pitchford, N. J., \& Mullen, K. T. (2005). The role of perception, language, and preference in the developmental acquisition of basic color terms. Journal of Experimental Child Psychology, 90, 275-302.

Richardson, R. T., Drexler, T. L.\& Delparte, D. M. (2014). Color and Contrast in E-learning Design: Journal of Online Learning and Teaching, 10(4), 654-670.

Schloss, K. B., Lessard I., Walmsley, C. S. \& Foley, K. (2018). Colour inference in visual communication: the meaning of colours in recycling. Cognitive Research: Principles and Implications. Published online 2018 Feb 21. doi: 10.1186/s41235-018-0090-y

Schutt, S., \&Linegar, D. (2013). We learn as we go: What five years playing with virtual worlds has taught us. International Journal of Virtual and Personal Learning Environments, 49(2), 124-136.

Simsek, O. (2016). Use of a game-based app as a learning tool for students with mathematics learning disabilities to increase fraction knowledge/skill (2016). Graduate Theses and Dissertations. http://scholarcommons.usf.edu/etd/6390

Skwarchuk, S., Sowinski, C., \& LeFevre, J. (2014). Formal and informal home learning activities in relation to children's early numeracy and literacy skills: The development of a home numeracy model. Journal of Experimental Child Psychology, 121(2014), 63-84

Smilek, D., Dixon, M. J.,Cudahy, C., \& Merikle, P. M. (2002). Synesthetic colour experiences influence memory.Psychological Science, 13(6), 548-552.

Usman, A. Odewumi, O., Obotuke, E., Apolola, E. \& Ogunyinka, C. O. (2014). Cultural and Creative Arts Book One for Junior Secondary Schools. Ibadan: Spectrum Books Limited.

Wastiau, P., Kearney, C., \& Van den Berghe, W. (2009). How are digital games used in schools? European School net. 2009. Retrieved from http://games.eun.org/upload/gis-synthesis_report_en.pdf

Wendel, V., Hertin, F., Göbel, S. and Steinmetz, R. (2010). Collaborative Learning by means of Multiplayer Serious Games. In Xiangeng Luo, Marc Spaniol, Lizhe Wang. Qing Li, Wolfgang Neidl, Wu Zhang: Proceedings of International Conference on Web-Based Learning, 2010, vol, 6483, p. 289-298. (https://link.springer.com/chapter/10.1007/978-3-642-17407-0_30\# citeas

Westfall, R. S. (1962). The development of Newton's theory of colour. Isis, 53(3), 339-400.

Zirawaga, V. S., Olusanya, A. I. \&Maduku, T. (2017) Gaming in Education: Using Games as a Support Tool to Teach History. Journal of Education and Practice, 8(15), 54-64.

\section{Authors}

\section{Micheal Olubunmi Odewumi, PhD}

University of Ilorin, Faculty of Education, Department of Educational Technology, Ilorin, Nigeria, email: agbegilerabunmi2@gmail.com

Univerza Ilorin, Pedagoška fakulteta, Oddelek za izobraževalno tehnologijo, Ilorin, Nigeria, e-pošta: agbegilerabunmi2@gmail.com 


\section{Adekunle Olusola Otunla, PhD}

Afe Babalola University, Department of Media \& Communication Studies, Ado Ekiti, Nigeria, e-mail: otunlaao@abuad.edu.ng

Univerza Afe Babalola, Oddelek za medijske in komunikacijske študije, Ado Ekiti, Nigeria, e-pošta: ounlaao@abuad.edu.ng

\section{Tayo Abass Bada, PhD}

Obafemi Awolowo University, Faculty of Education, Department of Educational Technology, Ile-Ife, Osun State Nigeria, e-mail: badatayo2@yahoo.com

Univera Obafemi Awolowo, Pedagoška fakulteta, Oddelek za izobraževalno tehnologijo, Ile-Ife, Osun

State Nigeria, e-pošta: badatayo2@yahoo.com 